\title{
SINTESA POP FAT MELALUI INTERESTERIFIKASI DAN FRAKSINASI BERBAHAN MINYAK SAWIT DAN OLEIN SUPER TERHIDROGENASI
}

\author{
[Synthesis of POP Fat via Interesterification and Fractionation Based on \\ Plam Oil and Hydrogenated Super Olein]
}

\author{
Hasrul Abdi Hasibuan ${ }^{1) \star}$, Syamsyah Fitri' ${ }^{2)}$, dan Aga Prima Hardika ${ }^{1)}$ \\ 1) Pusat Penelitian Kelapa Sawit, JI.Brigjend Katamso No.51, Medan \\ 2) Pendidikan Tinggi Kimia Industri, Jl. Menteng, Medan
}

Diterima 16 Juni 2015 / Disetujui 24 Desember 2015

\begin{abstract}
Interesterification of fat blends containing palm oil (RBDPO) and hydrogenated super olein (HSOL) at weight ratios of $3: 1,2: 1,1: 1,1: 2$ and $1: 3$ and fractionation was studied for production $P O P$ fat. $P O P$ fat is cocoa butter equivalent (CBE) which contains high triglyceride of 1,3-dipalmitoyl-2-oleoyl-glycerol (POP) and its can be used as alternative fat for cocoa butter with the standard i.e. triglyceride composition of saturated-unsaturated-saturated (SUS) more than $65 \%$ and melting point about of $32-35^{\circ} \mathrm{C}$. Interesterification was conducted chemically using sodium methoxide. Then, interesterified product was fractionated two stages using hexane and acetone as solvent, respectively. Interesterification of the subtrates resulted change of triglycerides composition of PPP, PPS, POP, POS and POO which were showed with the concentration of several triglycerides were increased, some were decreased and several new triglycerides were formed. The change of triglyceride structure cause melting point and solid fat content were decreased. Fractionation 2 stages of interesterified product resulted fat containing high triglyceride of POP (above 62\%) and POS range of $10-17 \%$ and melting point about of $35-39^{\circ} \mathrm{C}$. This product can be categorized as CBE which produced from the substrate of RBDPO to HSOL at weight ratio was $2: 1$ with characteristic i.e. POP $68.2 \%$, POS $10.8 \%$ and melting point of $35^{\circ} \mathrm{C}$.
\end{abstract}

Keywords: cocoa butter equivalent, interesterification, palm oil, POP fat, sodium methoxied

\section{ABSTRAK}

Interesterifikasi campuran antara refined bleached deodorized palm oil (RBDPO) dan olein super terhidrogenasi (HSOL) pada rasio berat 3:1, 2:1, 1:1, 1:2 dan 1:3 yang dilanjutkan dengan fraksinasi telah dilakukan untuk mensintesis POP fat. POP fat merupakan cocoa butter equivalent (CBE) yang mengandung trigliserida 1,3-dipalmitoyl-2-oleoyl-glycerol (POP) dan dapat digunakan sebagai lemak pengganti cocoa butter dengan standar meliputi komposisi trigliserida saturated-unsaturated-saturated (SUS) $>65 \%$ dan titik leleh berkisar $32-35^{\circ} \mathrm{C}$. Interesterifikasi dilakukan secara kimiawi menggunakan natrium metoksida. Selanjutnya, produk terinteresterifikasi difraksinasi dua tahap masing-masing menggunakan pelarut heksan dan aseton. Interesterifikasi dari substrat menghasilkan perubahan komposisi trigliserida PPP, PPS, POP, POS dan POO yang ditunjukkan dengan konsentrasi beberapa trigliserida meningkat, beberapa menurun dan ada terbentuk trigliserida baru. Perubahan komposisi trgiliserida ini menyebabkan titik leleh dan kandungan lemak padat menurun. Fraksinasi 2 tahapan dari produk terinteresterifikasi menghasilkan lemak yang mengandung trigliserida POP tinggi (lebih dari $62 \%$ ) dan POS berkisar antara $10-17 \%$ serta titik leleh sebesar $35-39^{\circ} \mathrm{C}$. Produk yang dihasilkan ini dapat dikategorikan sebagai CBE yang dihasilkan dari campuran RBDPO dan HSOL pada rasio 2:1 dengan komposisi POP $68,2 \%$, POS $10,8 \%$ dan titik leleh $35^{\circ} \mathrm{C}$.

Kata kunci: cocoa butter equivalent, interesterifikasi, minyak sawit, natrium metoksida, POP fat

\section{PENDAHULUAN}

Cocoa Butter (CB) mengandung asam palmitat (C16:0) $24,4 \%$, asam stearat (C18:0) $33,6 \%$, asam oleat (C18:1) 37\%, asam linoleat (C18:2) 3,4\% dan yang lainnya $1,6 \%$. Komposisi trigliserida CB adalah 1,3-dipalmitoyl-2-oleoyl-glycerol (POP) 10-20\%, 1(3) -palmitoyl-3(1)stearoyl-2-oleoylglycerol (POS) 40$55 \%$, SOS (1,3-distearoyl-2-oleoylglycerol) $20-30 \%$ dan asam oleat berada pada sn-2 dari gliserol (Tchobo et al., 2009; Shekarchizadeh et al., 2009; Shekarchizadeh et al., 2014).

*Penulis Korespondensi:

E-mail: hasibuan_abdi@yahoo.com 
Komposisi trigliserida yang spesifik, CB memiliki titik leleh yang sempit berkisar antara $32-35^{\circ} \mathrm{C}$ sehingga mudah mencair di dalam mulut namun berbentuk padat pada suhu ruang (Zaidul et al., 2007; Liu et al., 2007). Cocoa butter memiliki harga tertinggi dari semua jenis minyak dan lemak komersial dikarenakan oleh ketersediaannya rendah dan permintaannya tinggi (Jahurul et al., 2014). Sebagai alternatif CB dikembangkan produk yang menyerupainya seperti cocoa butter substitute (CBS) jenis laurat atau non laurat dan cocoa butter equivalent (CBE) (Nazaruddin et al., 2011; Naik dan Kumar, 2014). CBS memiliki kemiripan sifat fisika dengan $C B$ sementara CBE mirip secara fisika dan kimia, oleh karena itu, CBE dapat dicampur dengan CB. (O'brien, 2004; Naik dan Kumar, 2014). CBE memiliki harga $30 \%$ lebih murah dibandingkan dengan CB sehingga pencampuran antara keduanya dapat menekan biaya produksi dalam pembuatan cokelat (Zaliha dan Norizzah, 2012).

Di Indonesia, CBE secara komersial telah dihasilkan dari minyak sawit (refined bleached deodorized palm oil, RBDPO) yang difraksinasi multitahap hingga 5 kali tahapan. Produk yang dihasilkan dikenal sebagai hard palm mid fraction (hard PMF) yang memiliki bilangan iodin 33,8-36,2 Wijs. Namun dengan cara ini, waktu untuk menghasilkan CBE relatif lama, biaya tinggi dan rendemennya rendah (Zaidul et al., 2007; Elisabeth, 2009). Selain CBE, CBS jenis laurat dan non laurat juga telah dihasilkan menggunakan teknologi hidrogenasi dan fraksinasi. CBS non laurat yang dihasilkan dari minyak sawit mengandung asam lemak trans (asam elaidat) tinggi. Hasibuan dan Siahaan, 2013 melaporkan bahwa kadar asam lemak trans pada CBS non laurat yang dihasilkan di Indonesia sebesar 52,02$58,17 \%$. Cara lain untuk menghasilkan CBE adalah dengan interesterifikasi antara minyak dan lemak. Ciftci et al., 2008 telah melakukan asidolisis asam palmitat dan stearat ke dalam triolein. Sementara, Mohamed, 2012 telah melakukan interesterifikasi enzimatis antara palm olein dan asam lemak jenuh destilat. Selain itu, Abigor et al., 2003 dan Soekapitojo et al., 2009 melakukan interesterifikasi fraksi minyak sawit dengan minyak kedelai terhidrogenasi sebagai asil donor stearat.

Minyak sawit jenis olein super memiliki bilangan iodin berkisar 60-64 Wijs dengan kandungan asam oleat $42,61-46,03 \%$ dan linoleat 11,37-14,07\% (Hasibuan, 2012). Hidrogenasi olein super mengkonversi asam oleat, linoleat dan linolenat menjadi stearat. Dengan demikian, olein super terhidrogenasi (HSOL) dapat digunakan sebagai asil donor palmitat dan stearat bagi RBDPO dalam sintesa CBE yang rendah asam lemak trans. Pada penelitian ini dilakukan sintesa POP fat sebagai CBE melalui interesterifikasi antara RBDPO dan HSOL secara kimiawi yang dilanjutkan dengan fraksinasinya. Produk yang dihasilkan diharapkan memiliki karakteristik yang menyerupai CBE. Selain itu, penelitian ini juga mempelajari pengaruh berbagai rasio berat substrat terhadap karakteristik produk CBE yang dihasilkan, terutama komposisi trigliserida dan profil pelelehannya.

\section{BAHAN DAN METODE}

\section{Bahan}

Bahan yang digunakan dalam penelitian ini antara lain bahan utama refined bleached deodorized palm oil (RBDPO) dan olein super (PT. Wilmar Internasional, Sumatera Utara). Sebagai pembanding digunakan POP fat komersial (PT. Wilmar Internasional, Sumatera Utara) dan cocoa butter (CB) (Pusat Penelitian Kopi dan Kakao).

\section{Persiapan hydrogenated super olein (HSOL)}

Hydrogenated super olein (HSOL) dibuat dengan cara hidrogenasi olein super yang dilakukan pada reaktor bertekanan. Sebanyak $1000 \mathrm{~g}$ olein super dihidrogenasi dengan bantuan katalis nikel $0,5 \%$ (Engelhard De Meen, Germany) dan gas hidrogen teknis (PT. Tri Gasses, Indonesia) pada tekanan 7,5 bar, suhu reaksi $170^{\circ} \mathrm{C}$, kecepatan pengadukan $500 \mathrm{rpm}$ dan waktu reaksi selama 8 jam. Setelah waktu tercapai produk hidrogenasi didinginkan hingga suhu $80-90^{\circ} \mathrm{C}$ dan selanjutnya disaring menggunakan kertas saring Whatman No. 42. Produk HSOL kemudian dideodorisasi pada suhu $245^{\circ} \mathrm{C}$ selama 2 jam. Peralatan untuk deodorisasi dirancang menggunakan labu leher 3 (Pyrex, Germany), kondensor (Pyrex, Germany), pompa vakum (Vacuubrand 2,5, Germany) dan elektromantel (Shin Saeng, China). Selanjutnya, produk HSOL dikarakterisasi meliputi titik leleh dan komposisi asam lemak.

\section{Interesterifikasi}

Interesterifikasi antara RBDPO dan olein super terhidrogenasi dilakukan pada rasio berat $3: 1,2: 1$, $1: 1,1: 2$, dan 1:3 menggunakan katalis natrium metoksida (Merck, Germany). Sebanyak $50 \mathrm{~g}$ campuran RBPDO dan olein super terhidrogenasi dengan rasio berat tertentu dipanaskan pada suhu $90^{\circ} \mathrm{C}$ selama 15 menit menggunakan hot plate (Thermo Scientific, Germany). Natrium metoksida sebanyak 0,4\% (b/b) (Merck, Germany) dari substrat ditambahkan, kemudian campuran diaduk pada kecepatan $200 \mathrm{rpm}$ dan dipanaskan pada suhu $90^{\circ} \mathrm{C}$ selama 1 jam. Pada akhir reaksi ditambahkan asam sitrat $(25 \%)$ sebanyak $1 \%$ dari substrat dan diaduk selama 15 menit. Produk interesterifikasi dicuci menggunakan air bersuhu $90^{\circ} \mathrm{C}$ sebanyak 3 kali. Setiap perlakuan dilakukan ulangan sebanyak 2 kali. Selanjutnya, produk interesterifikasi dikarakterisasi meliputi titik leleh, komposisi trigliserida dan kandungan lemak padat. 


\section{Fraksinasi}

Produk interesterifikasi dilarutkan dengan heksan pada rasio berat $1: 5$ dan dinetralisasi dengan $\mathrm{NaOH} \quad 0,1 \mathrm{~N}$ (dalam etanol 50\% dengan indikator PP). Lapisan atas disaring menggunakan $\mathrm{Na}_{2} \mathrm{SO}_{4}$ dan didinginkan dalam water bath (Thermo Scientific, Germany) pada $4^{\circ} \mathrm{C}$ selama 4 jam. Setelah waktu tercapai padatan disaring dan fraksi cair dihilangkan pelarut heksan dengan cara penguapan menggunakan rotary evaporator (Buchi, Switzerland). Hasil evaporasi dilarutkan dengan aseton pada rasio berat 1:5 dan didinginkan dalam water bath pada $4^{\circ} \mathrm{C}$ selama 4 jam. Setelah waktu tercapai fraksi padat dipisahkan dan pelarut aseton dihilangkan dengan cara penguapan menggunakan rotary evaporator. Setiap perlakuan dilakukan ulangan sebanyak 2 kali. Selanjutnya, produk fraksinasi dikarakterisasi meliputi titik leleh, komposisi trigliserida dan kandungan lemak padat.

\section{Analisa komposisi asam lemak}

Analisa komposisi asam lemak ditentukan menggunakan alat kromatografi gas (GC-2010, Shimadzu) dengan mengacu pada metode standar AOCS, 1997 Official Method Ce 1b-89. Sebanyak $0,025 \mathrm{~g}$ sampel ditambahkan $1,5 \mathrm{~mL} \mathrm{NaOH}$ metanolik $0,5 \mathrm{~N}$ (Merck, Germany). Campuran kemudian dipanaskan dalam water bath pada suhu $80^{\circ} \mathrm{C}$ selama 5 menit. Campuran didinginkan kemudian ditambahkan $2 \mathrm{~mL} \mathrm{BF} 3$ metanol $(14 \% \mathrm{~b} / \mathrm{v})$ (Merck, Germany) dan dipanaskan kembali dalam water bath pada suhu $80^{\circ} \mathrm{C}$ selama 30 menit. Campuran didinginkan kemudian ditambahkan $1 \mathrm{~mL}$ isooktan (Merck, Germany) dan diaduk selama 1-2 menit. Campuran ditambahkan $5 \mathrm{~mL} \mathrm{NaCl}$ jenuh (Merck, Germany) dan diaduk. Lapisan isooktana dipisahkan dan dipindahkan ke dalam vial lalu diinjeksikan sebanyak $0,1 \mu \mathrm{L}$ ke dalam kromatografi gas. Kolom yang digunakan dalam analisa komposisi asam lemak adalah DB-23 J\&W Scientific. Kondisi operasi kromatografi gas adalah suhu detektor $260^{\circ} \mathrm{C}$, suhu injektor $260^{\circ} \mathrm{C}$. Temperatur oven terprogram dengan kondisi awal $70^{\circ} \mathrm{C}$, kemudian dinaikkan sebesar $20^{\circ} \mathrm{C}$ /menit hingga $180^{\circ} \mathrm{C}$, kemudian naik $1^{\circ} \mathrm{C} /$ menit hingga $182^{\circ} \mathrm{C}$, kemudian naik $10^{\circ} \mathrm{C} /$ menit hingga $220^{\circ} \mathrm{C}$ dan ditahan selama 2 menit.

\section{Analisa komposisi trigliserida (TG)}

Analisis komposisi TG dilakukan menggunakan kromatografi gas. Sampel dilarutkan dalam heksan (Merck, Germany) dengan konsentrasi 1\%, lalu disuntikkan ke dalam GC sebanyak $0,1 \mu \mathrm{L}$. Kolom yang digunakan adalah DB-17 HT (panjang $30 \mathrm{~m}$, ketebalan film $0,15 \mathrm{~m}$, dan ukuran diameter
$0,32 \mathrm{~mm}$ ). Kondisi GC diatur dengan temperatur injektor $350^{\circ} \mathrm{C}$ dan detektor $350^{\circ} \mathrm{C}$. Program temperatur oven adalah suhu awal $330^{\circ} \mathrm{C}$ kemudian ditahan selama 2 menit. Selanjutnya suhu dinaikkan $5^{\circ} \mathrm{C} /$ menit hingga $350^{\circ} \mathrm{C}$ dan ditahan selama $350^{\circ} \mathrm{C}$. Analisis komposisi TG dilakukan terhadap substrat sebelum dan sesudah reaksi interesterifikasi serta hasil fraksinasi.

\section{Analisa kandungan lemak padat solid fat content (SFC)}

Analisis SFC ditentukan menggunakan alat nuclear magnetic resonance (NMR) (mqone, Bruker) dengan mengacu pada metode standar AOCS, 1997 Official Method Cd 16b-93. Sampel minyak dipanaskan dalam water bath pada suhu $80^{\circ} \mathrm{C}$. Sampel yang telah cair dimasukkan ke dalam 12 tabung untuk analisa SFC dengan ketinggian sampel sekitar $4 \pm 1 \mathrm{~cm}$. Sampel dipanaskan di dalam water bath pada suhu $100^{\circ} \mathrm{C}$ selama 15 menit kemudian dipindahkan ke water bath bersuhu $60^{\circ} \mathrm{C}$ selama 30 menit. Sampel dipindahkan ke water bath suhu $0^{\circ} \mathrm{C}$ selama 90 menit. Selanjutnya sampel dipindah ke water bath suhu $26^{\circ} \mathrm{C}$ selama 40 jam. Sampel dipindahkan lagi pada water bath suhu $0^{\circ} \mathrm{C}$ selama 90 menit. Setelah itu, setiap 2 tabung sampel dipindahkan ke water bath dengan suhu masing-masing $10,20,25,30,35,40^{\circ} \mathrm{C}$ selama 30 35 menit. Kandungan lemak padat setiap sampel pada masing-masing suhu diukur dengan memasukkannya ke dalam holder pada alat NMR dengan metode Stab AOCS method. Kalibrasi NMR menggunakan standar SFC 0, 31,5 dan 72,9\%.

\section{Analisa titik leleh (slip melting point)}

Analisis titik leleh (AOCS, 1997 Official Methods Cc 3-25) dilakukan terhadap bahan baku, campuran sebelum dan sesudah reaksi interesterifikasi serta hasil fraksinasi. Sampel dilelehkan dalam water bath pada suhu $80^{\circ} \mathrm{C}$ dan dimasukkan ke dalam pipa kapiler (3 buah) setinggi $1 \mathrm{~cm}$. Sampel disimpan dalam refrigerator (Panasonic, Indonesia) pada suhu $4-10^{\circ} \mathrm{C}$ selama 16 jam. Setelah waktu tercapai, pipa kapiler diikatkan pada termometer (Alla, France) dan kemudian dimasukkan ke dalam beaker glas (600 mL) (Pyrex, Germany) yang berisi air (sekitar $300 \mathrm{~mL}$ ). Suhu air dalam beaker glas diatur pada suhu $8-10^{\circ} \mathrm{C}$ di bawah titik leleh sampel dan suhu air dipanaskan menggunakan hot plate secara perlahan (dengan kenaikan $0,5^{\circ} \mathrm{C}-1^{\circ} \mathrm{C} /$ menit) dengan pengadukan. Pemanasan dilanjutkan dan suhu diamati dari saat sampel meleleh sampai sampel naik pada tanda batas atas. Titik leleh dihitung berdasarkan rata-rata suhu dari ketiga sampel yang diamati. 


\section{HASIL DAN PEMBAHASAN}

\section{Olein super terhidrogenasi}

Hidrogenasi mengkonversi asam lemak tidak jenuh (oleat, linoleat dan linolenat) menjadi asam lemak jenuh (stearat). Perubahan komposisi asam lemak ini khususnya asam stearat dilakukan agar dapat digunakan sebagai asil stearat pada minyak atau lemak lain seperti RBDPO. Pada penelitian ini, hidrogenasi olein super telah mengkonversi asam oleat (C18:1) 42,1\% dan linoleat (C18:2) 12,7\% menjadi asam stearat (C18:0) $49.7 \%$ dan menyisakan asam elaidat sebesar $6,7 \%$. Akibat dari perubahan komposisi asam lemak ini menyebabkan titik leleh juga berubah. Produk HSOL memiliki titik leleh sebesar $55,4^{\circ} \mathrm{C}$ meningkat dari bahan bakunya $12,8^{\circ} \mathrm{C}$.

Asam elaidat merupakan bentuk trans daripada asam oleat yang timbul akibat dari proses hidrogenasi yang belum sempurna atau total. Kandungan asam elaidat pada produk hidrogenasi ini relatif rendah dibandingkan dengan produk hidrogenasi olein super dalam menghasilkan produk CBS jenis non laurat. Hasibuan dan Siahaan, 2013 melaporkan bahwa produk CBS non laurat dari minyak sawit yang dihasilkan oleh industri CBS di Indonesia mengandung asam elaidat sebesar $52,02-58,17 \%$.

\section{Karakteristik RBDPO dan HSOL setelah interes- terifikasi}

Komposisi trigliserida (TG) dari RBDPO, HSOL dan campurannya dengan beberapa rasio campuran ditunjukkan pada Tabel 1. Komposisi TG utama dari RBDPO adalah 1,2,3-tripalmitoyl-glycerol (PPP) 15,6\%, POP 36,1\% dan 1(3)-palmitoyl-2,3(1)-dioleylglycerol (POO) $19,6 \%$ sedangkan HSOL adalah 1(3),2-dipalmitoyl-3(1)-stearoyl-glycerol

49,3\%, 1(3)-palmitoyl-2,3(1)-distearoyl-glycerol (PS S) $25,2 \%$ dan POS $17,8 \%$. Kandungan POP pada RBDPO relatif tinggi namun untuk merubah karakteristiknya menyerupai $\mathrm{CB}$ harus dilakukan fraksinasi multi tahap sebanyak 5 kali dengan produk yang dihasilkan memiliki kandungan POP lebih dari $65 \%$ (Elisabeth, 2009). Atas dasar tersebut, penelitian ini dilakukan untuk mempersingkat tahapan proses dengan menambahkan HSOL yang mengandung asam palmitat dan stearat tinggi ke dalam RBDPO.

Komposisi TG dari campuran antara RBDPO dan HSOL merupakan kombinasi yang linear dari komponen lemak dalam campuran. Artinya, dengan meningkatnya persentasi RBDPO pada campuran maka persentasi POP, POO dan TG lain meningkat. RBDPO mengandung sedikit asam stearat pada struktur TG sementara HSOL mengandung cukup banyak asam stearat pada posisi sn-1 dan sn-2. Dari komposisi TG RBDPO mengindikasikan bahwa RBDPO cukup baik sebagai bahan baku karena kandungan asam oleat yang tinggi pada posisi sn-2. Menurut Hossain, 2013 bahwa minyak sawit mengandung saturated-monounsaturated-saturated tinggi yang juga merupakan komponen trigliserida tertinggi dari CB. Pinyaphong dan Phutrakul, 2009 juga menyatakan bahwa dalam sintesis CBE asam oleat berada pada sn-2 sangat penting agar asil donor palmitat maupun stearat dapat terikat pada sn-1 dan sn-3 sehingga diperoleh titik leleh yang sempit pada produknya.

Tabel 1 menunjukkan bahwa interesterifikasi dari RBDPO dan HSOL menghasilkan campuran dengan komponen asilgliserol yang berbeda dari bahan bakunya. Interesterifikasi antara RBDPO dan HSOL menyebabkan beberapa TG meningkat, sebagian menurun dan ada yang membentuk senyawa TG baru. Abigor et al., 2003; Ciftci et al., 2008 dan Soekopitojo et al., 2009 juga menyatakan hal yang sama bahwa dengan interesterifikasi akan mengubah komponen trigliserida dari lemak dan minyak. Komponen TG yang berubah adalah PPP, PPS, POP, POS, dan POO dengan perubahan yang cukup besar ketika jumlah HSOL meningkat. Kandungan SOS dalam produk interesterifikasi campuran tidak meningkat disebabkan oleh komponen $\mathrm{OOO}$ dalam campuran rendah serta kandungan SSS pada HSOL hanya sebesar $2,4 \%$.

Interesterifikasi kimiawi menyebabkan terjadinya pertukaran asil pada gliserida secara acak yang ditunjukkan dengan tidak adanya pola peningkatan maupun penurunan pada setiap komponen TG yang berubah dengan meningkatnya jumlah HSOL. Beberapa peneliti juga telah menyatakan hal yang sama bahwa interesterifikasi secara kimiawi menyebabkan pertukaran asil pada TG terjadi secara acak dari asam lemak penyusun trigliserida (Idris dan Dian, 2005; Pinyaphong dan Phutrakul, 2009; Fauzi et al., 2013; Amir et al., 2012). Sementara interesterifikasi secara enzimatis menggunakan enzim yang spesifik sn-1,3 akan merubah komponen trigliserida pada posisi sn-1,3. Perpindahan asil merupakan permasalahan yang serius dalam sintesa CBE yang dapat menentukan karakteristik dari produk yang dihasilkan serta menunjukkan kemiripannya denga CB (Kadivar et al., 2013).

Interesterifikasi juga memberikan nilai kandungan lemak padat (solid fat content, SFC) berbeda dari sebelum reaksi yang disebabkan oleh perubahan komposisi TG. SFC dari campuran RBDPO/HSOL merepresentasikan kombinasi secara linear dari RBDPO dan HSOL (Gambar 1). Artinya, nilai SFC akan meningkat dengan peningkatan persentasi HSOL dan menurun dengan peningkatan persentasi RBDPO. Campuran yang telah diinteresterifikasi memberikan nilai SFC lebih rendah dibandingkan sebelum diinteresterifikasi. 
Tabel 1. Komposisi trigliserida dari campuran RBDPO dan HSOL sebelum dan setelah interesterifikasi

\begin{tabular}{|c|c|c|c|c|c|c|c|c|c|c|c|c|}
\hline \multirow{3}{*}{$\begin{array}{c}\text { Trigliserida } \\
\text { (\% berat) }\end{array}$} & \multicolumn{2}{|c|}{ Substrat } & \multicolumn{10}{|c|}{ Rasio Berat Substrat (RBDPO:HSOL) $n=2$} \\
\hline & \multirow{2}{*}{ RBDPO } & \multirow{2}{*}{ HSOL } & \multicolumn{2}{|c|}{$\mathrm{A}(3: 1)$} & \multicolumn{2}{|c|}{$\mathrm{B}(2: 1)$} & \multicolumn{2}{|c|}{$C(1: 1)$} & \multicolumn{2}{|c|}{$D(1: 2)$} & \multicolumn{2}{|c|}{$E(1: 3)$} \\
\hline & & & $\mathrm{BIE}$ & AIE & $\mathrm{BIE}$ & AIE & $\mathrm{BIE}$ & AIE & $\mathrm{BIE}$ & AIE & $\mathrm{BIE}$ & AIE \\
\hline MMP & 1 & 0 & $1,9 \pm 0,2$ & 0 & $1,8 \pm 0,3$ & 0 & 0 & 0 & $0,8 \pm 0,5$ & 0 & $0,9 \pm 0,3$ & 0 \\
\hline MPP & 0,9 & 0 & $0,6 \pm 0,1$ & $2,1 \pm 0,5$ & $0,7 \pm 0,5$ & $1,2 \pm 0,3$ & $1,5 \pm 0,5$ & $2,1 \pm 0,4$ & $0,1 \pm 0,1$ & $0,1 \pm 0,1$ & 0 & 0 \\
\hline PPP & 15,6 & 3,9 & $13,2 \pm 0,2$ & $13,4 \pm 0,6$ & $12,4 \pm 0,5$ & $7,8 \pm 0,5$ & $11 \pm 0,4$ & $12,1 \pm 0,3$ & $7,5 \pm 0,3$ & $13,2 \pm 0,4$ & $6,6 \pm 0,3$ & $12,6 \pm 0,4$ \\
\hline MOP & 3,4 & 0 & $3,7 \pm 0,3$ & $3,7 \pm 0,2$ & $3,2 \pm 0,6$ & $0,2 \pm 0,7$ & $2,7 \pm 0,7$ & $3 \pm 0,3$ & $1,5 \pm 0,3$ & $3,3 \pm 0,4$ & $0,7 \pm 0,2$ & $2,8 \pm 0,4$ \\
\hline MLP & 1 & 0 & 0 & $0,2 \pm 0,1$ & 0 & $0,5 \pm 0,8$ & 0 & 0 & 0 & 0 & 0 & 0 \\
\hline PPS & 0,2 & 49,9 & $12,4 \pm 0,5$ & $11,2 \pm 0,4$ & $14,9 \pm 0,2$ & $31,7 \pm 0,9$ & $21,4 \pm 0,7$ & $23,7 \pm 0,2$ & $24 \pm 0,4$ & $15,5 \pm 0,5$ & $32 \pm 0,6$ & $34,2 \pm 0,5$ \\
\hline POP & 36,1 & 0 & $35,8 \pm 0,9$ & $39,4 \pm 0,6$ & $35 \pm 0,8$ & $25,4 \pm 0,4$ & $31,2 \pm 0,9$ & $31,9 \pm 0,5$ & $23,9 \pm 0,4$ & $36,8 \pm 0,6$ & $20,9 \pm 0,7$ & $30,2 \pm 0,5$ \\
\hline PLP & 9,5 & 0 & $5,1 \pm 0,5$ & $6,7 \pm 0,8$ & $5,6 \pm 0,4$ & $1,8 \pm 0,6$ & $3,7 \pm 0,6$ & $4 \pm 0,4$ & $2,1 \pm 0,6$ & $5,4 \pm 0,7$ & 0 & $1,8 \pm 0,2$ \\
\hline PSS & 0 & 25,3 & $8,3 \pm 0,2$ & $4,8 \pm 0,9$ & $9,5 \pm 0,6$ & $7,8 \pm 0,7$ & $10,8 \pm 0,6$ & $11,1 \pm 0,4$ & $17,9 \pm 0,7$ & $11,8 \pm 0,5$ & $18,9 \pm 0,7$ & $13,5 \pm 0,7$ \\
\hline POS & 4,1 & 17,8 & $5,8 \pm 0,8$ & $4,6 \pm 0,2$ & $6,3 \pm 0,7$ & $9,8 \pm 0,8$ & $7,4 \pm 0,4$ & $5 \pm 0,6$ & $10,1 \pm 0,9$ & $6,4 \pm 0,7$ & $12 \pm 0,8$ & $4,9 \pm 0,4$ \\
\hline POO & 19,6 & 0 & $11,1 \pm 0,5$ & $13,7 \pm 0,3$ & $9,5 \pm 0,7$ & $8,7 \pm 0,8$ & $9,3 \pm 0,3$ & $7,1 \pm 0,7$ & $9,4 \pm 0,5$ & $5 \pm 0,5$ & $6 \pm 0,4$ & $1,0 \pm 0,1$ \\
\hline PLO & 5,4 & 0 & $2,1 \pm 0,7$ & $0,1 \pm 0,6$ & $1,1 \pm 0,7$ & $5,1 \pm 0,5$ & $1 \pm 0,3$ & 0 & $0,9 \pm 0,5$ & $2,4 \pm 0,4$ & 0 & 0 \\
\hline PLL & 0,2 & 0 & 0 & $0,1 \pm 0,3$ & 0 & 0 & 0 & 0 & 0 & $0,1 \pm 0,1$ & 0 & 0 \\
\hline SSS & 0 & 2,4 & 0 & 0 & 0 & 0 & 0 & 0 & $1,8 \pm 0,3$ & 0 & $2 \pm 0,3$ & 0 \\
\hline sos & 0,3 & 0,7 & 0 & 0 & 0 & 0 & 0 & 0 & 0 & 0 & 0 & 0 \\
\hline SOO & 0,9 & 0 & 0 & 0 & 0 & 0 & 0 & 0 & 0 & 0 & 0 & 0 \\
\hline O০০ & 1,6 & 0 & 0 & 0 & 0 & 0 & 0 & 0 & 0 & 0 & 0 & 0 \\
\hline SLO & 0,1 & 0 & 0 & 0 & 0 & 0 & 0 & 0 & 0 & 0 & 0 & 0 \\
\hline OLO & 0,1 & 0 & 0 & 0 & 0 & 0 & 0 & 0 & 0 & 0 & 0 & 0 \\
\hline SOA & 0 & 0 & 0 & 0 & 0 & 0 & 0 & 0 & 0 & 0 & 0 & 0 \\
\hline
\end{tabular}

Keterangan: $\mathrm{BIE}=$ sebelum interesterifikasi, AIE=s etelah interesterifikasi, 1(3),2-dimiristoyl-3(1)-palmitoyl-glycerol(MMP), 1(3)-miristoyl-2,3(1)-dipalmitoyl-glycerol (MPP), 1,2,3-tripalmitoyl-glycerol (PPP), 1(3)-miristoyl-2-oley-3(1)-palmitoyl-glycerol (MOP), 1(3)-miristoyl-2-linoleyl-3(1)-palmitoyl-glycerol (MLP), 1(3),2-dipalmitoyl-3(1)stearoyl-glycerol (PPS), 1,3-dipalmitoyl-2-oleoyl-glycerol (POP), 1,3-dipalmitoyl-2-linoleyl-glycerol (PLP), 1(3)-palmitoyl-2,3(1)-distearoyl-glycerol (PSS), 1(3)palmitoyl-3(1) stearoyl-2-oleoyl-glycerol(POS), 1(3)-palmitoyl-2,3(1)-dioleyl-glycerol (POO), 1 (3)-palmitoyl-2-linoleyl-3(1)-linoleyl-glycerol (PLO), 1 (3)-palmitoyl-2,3(1)dilimoleyl-glycerol(PLL), 1,2,3-tristeroyl-glycerol(SSS), 1,3-disteroyl-2-oleoyl-glycerol(SOS), 1(3)-steroyl-2,3(1)-dioleyl-glycerol (SOO), 1,2,3-trioleyl-glycerol(OOO), 1(3)-steroyl-2-linoleyl-3(1)-oleyl-glycerol (SLO), 1,3-dioleyl-2-linoleyl-glycerol (OLO), 1(3)-steroyl-2-oleyl-3(1)-arachidat-glycerol (SOA) 

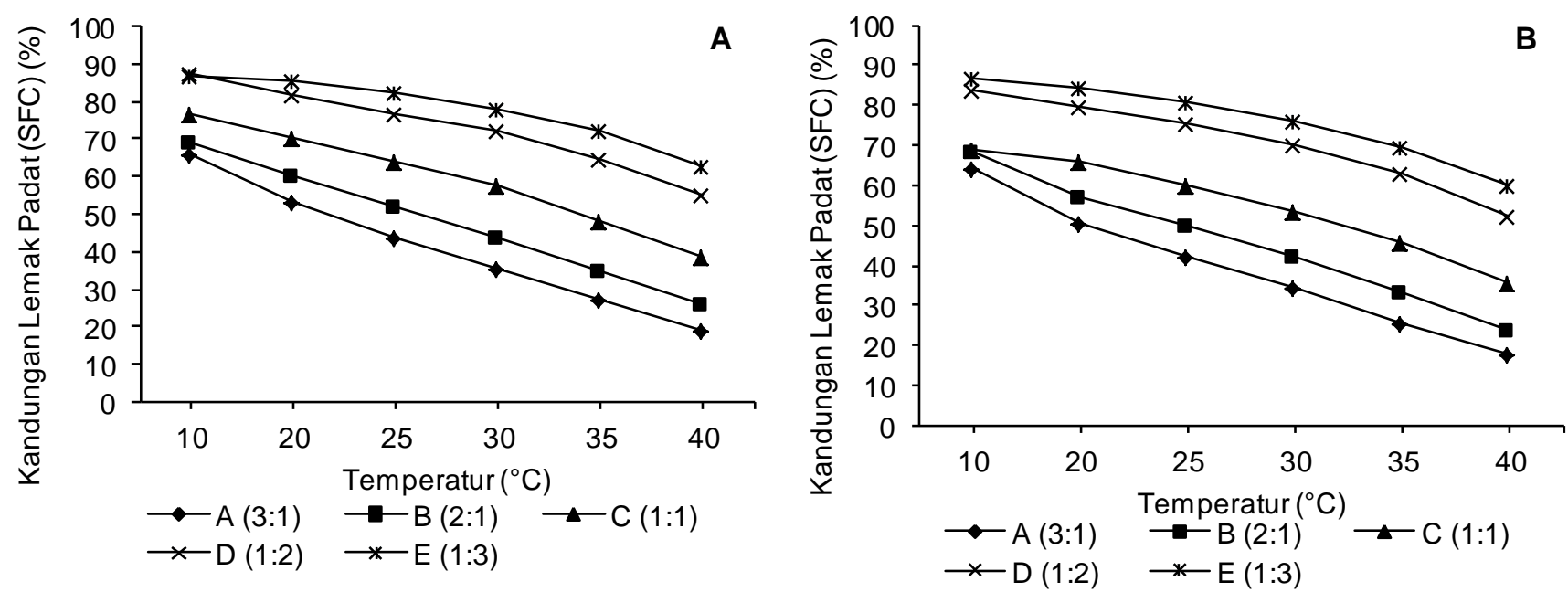

Gambar 1. Profil SFC campuran sebelum diinteresterifikasi (A) dan setelah diinteresterifikasi (B)

Campuran interesterifikasi berbentuk padat pada temperatur ruang dengan titik leleh berkisar antara $42,6-46,8^{\circ} \mathrm{C}$ sedikit menurun dengan sebelum interesterifikasi $\left(46-51^{\circ} \mathrm{C}\right)($ Tabel 2$)$. Titik leleh yang berbeda antara sebelum dengan sesudah interesterifikasi menunjukkan terjadinya perubahan komposisi trigliserida seperti yang telah dijelaskan sebelumnya.

Tabel 2. Titik leleh campuran RBDPO:HSOL sebelum dan sesudah interesterifikasi

\begin{tabular}{|c|c|c|c|}
\hline Campuran & Rasio & $\begin{array}{l}\text { MP Sebelum } \\
\text { Interesterifikasi } \\
\left({ }^{\circ} \mathrm{C}\right) \mathrm{n}=2\end{array}$ & $\begin{array}{l}\text { MP Setelah } \\
\text { Interesterifikasi } \\
\left({ }^{\circ} \mathrm{C}\right) \mathrm{n}=2\end{array}$ \\
\hline $\begin{array}{l}\text { RBDPO: } \\
\text { HSOL }\end{array}$ & $3: 1$ & $46,0 \pm 0,2$ & $42,6 \pm 0,8$ \\
\hline $\begin{array}{l}\text { RBDPO: } \\
\text { HSOL }\end{array}$ & $2: 1$ & $47,0 \pm 0,3$ & $43,6 \pm 0,3$ \\
\hline $\begin{array}{l}\text { RBDPO: } \\
\text { HSOL }\end{array}$ & $1: 1$ & $49,0 \pm 0,2$ & $45,0 \pm 0,5$ \\
\hline $\begin{array}{l}\text { RBDPO: } \\
\text { HSOL }\end{array}$ & $1: 2$ & $50,5 \pm 0,3$ & $46,0 \pm 0,4$ \\
\hline $\begin{array}{l}\text { RBDPO: } \\
\text { HSOL }\end{array}$ & $1: 3$ & $51,0 \pm 0,3$ & $46,8 \pm 0,7$ \\
\hline RBDPO & & 37,4 & \\
\hline HSOL & & 55,4 & \\
\hline $\mathrm{CB}^{1}$ & & $32-35$ & \\
\hline $\begin{array}{l}\text { CBE (POP } \\
\text { fat) }\end{array}$ & & $30,5-33,5$ & \\
\hline
\end{tabular}

\section{Fraksinasi campuran RBDPO dan HSOL setelah interesterifikasi}

Interesterifikasi antara RBDPO dengan HSOL menghasilkan asam lemak bebas $<2 \%$. Asam lemak bebas ini dihilangkan dengan cara netralisasi. Fraksinasi campuran RBDPO dan HSOL yang diinteresterifikasi secara bertingkat menggunakan heksan dan aseton menghasilkan POP fat dengan komponen POP > 62\% dan POS berkisar antara 10-
17\% (Tabel 3). Menurut Soekapitojo et al., 2011 bahwa lemak dikategorikan sebagai CBE bila mengandung StOSt $>65 \%(\mathrm{St}=$ saturated, $\mathrm{O}=$ oleic acid). Dengan demikian, POP fat yang dihasilkan pada penelitian ini dapat disebut sebagai $\mathrm{CBE}$ karena mengandung trigliserida POP dan POS tinggi dengan jumlah $>65 \%$.

Profil SFC dari POP fat ditunjukkan pada Gambar 2. SFC dari interesterifikasi campuran RBDPO dan HSOL berubah secara signifikan setelah difraksinasi. POP fat memiliki SFC yang lebih rendah pada temperatur $35^{\circ} \mathrm{C}$ dan $40^{\circ} \mathrm{C}$ dibandingkan dengan sebelum difraksinasi. Hal ini disebabkan meningkatnya saturated-unsaturated-saturated dan menurunnya saturated-saturated-saturated pada TG. Meskipun komposisi TG dari POP fat yang dihasilkan sedikit berbeda dengan $C B$ namun profil SFC-nya pada temperatur $10-30^{\circ} \mathrm{C}$ mirip sementara pada suhu $35^{\circ} \mathrm{C}$ dan $40^{\circ} \mathrm{C}$ sedikit lebih tinggi dibandingkan dengan $\mathrm{CB}$. Hal ini disebabkan oleh POP fat memiliki kandungan POP tinggi, POS rendah dan tidak mengandung SOS (Tabel 3). Sementara CB mengandung POP, POS dan SOS masing-masing sebesar 14,8; 36,8; dan 25,3\% (Soekapitojo et al., 2009).

Titik leleh POP fat yang diperoleh berkisar antara $35-39^{\circ} \mathrm{C}$ (Tabel 4) sementara $\mathrm{CB}$ berkisar antara $27-35^{\circ} \mathrm{C}$ (Zaidul et al., 2007) dan $32-35^{\circ} \mathrm{C}$ (Shekarchizadeh et al., 2009). Di samping itu, CBE yang pernah disintesis dari RBDPO dan metil stearat memiliki titik leleh $37-39^{\circ} \mathrm{C}$ (Pinyaphong dan Phutrakul, 2009), sementara interesterifikasi antara palm mid fraction dengan campuran asam stearat dan palmitat diperoleh produk dengan titik leleh $31,6^{\circ} \mathrm{C}$ (Mohamed, 2013). Mohamed 2012 menghasilkan CBE dengan titik leleh berkisar antara 34,7$39,6^{\circ} \mathrm{C}$ dari interesterifikasi palm olein dan asam lemak jenuh destilat. Abigor et al., 2003 melakukan interesterifikasi canola oil terhidrogenasi dan olive oil pada rasio 1:1 menghasilkan CBE dengan titik leleh 
$39^{\circ} \mathrm{C}$. Soekapitojo et al., 2009 juga melaporkan interesterifikasi palm mid fraction dan soyabean oil terhidrogenasi dengan titik leleh produk sebesar $31,8-33,4^{\circ} \mathrm{C}$.

Tabel 3. Komposisi TG dari fraksinasi 2 tahap dari campuran RBDPO dan HSOL terinteresterifikasi

\begin{tabular}{cccccc}
\hline Komposisi & \multicolumn{5}{c}{ Rasio Berat Substrat (RBDPO/HSOL) $\mathrm{n}$} \\
TG & \multicolumn{5}{c}{$=2$} \\
\cline { 2 - 6 } (\% berat) & $\mathrm{A}$ & $\mathrm{B}$ & $\mathrm{C}$ & $\mathrm{D}$ & $\mathrm{E}$ \\
& $(3: 1)$ & $(2: 1)$ & $(1: 1)$ & $(1: 2)$ & $(1: 3)$ \\
\hline PPP & $5,2 \pm$ & $4,5 \pm$ & $3,5 \pm$ & $5,7 \pm$ & $3,7 \pm$ \\
& 0,7 & 0,3 & 0,5 & 0,4 & 0,5 \\
MOP & $3,7 \pm$ & $4,5 \pm$ & $3,9 \pm$ & $4,8 \pm$ & $5 \pm$ \\
& 0,6 & 0,5 & 0,6 & 0,3 & 0,6 \\
PPS & $2,1 \pm$ & $2,4 \pm$ & $2,9 \pm$ & $3,1 \pm$ & $4,3 \pm$ \\
& 0,2 & 0,2 & 0,6 & 0,3 & 0,6 \\
POP & $69 \pm$ & $68,2 \pm$ & $67,8 \pm$ & $62,7 \pm$ & 62,6 \\
& 1,2 & 1,5 & 1,2 & 1,7 & $\pm 0,9$ \\
PLP & $4,6 \pm$ & $4,8 \pm$ & $4,0 \pm$ & $4,2 \pm$ & $2,4 \pm$ \\
& 0,8 & 0,7 & 0,6 & 0,5 & 0,5 \\
PSS & $0,3 \pm$ & 0 & 0 & $0,9 \pm$ & $0,4 \pm$ \\
& 0,6 & & & 0,1 & 0,8 \\
POS & $10 \pm$ & $10,8 \pm$ & $12,7 \pm$ & $12,3 \pm$ & 17,1 \\
& 0,6 & 0,9 & 0,5 & 0,6 & $\pm 0,7$ \\
POO & $5,2 \pm$ & $4,6 \pm$ & $5,1 \pm$ & $6,3 \pm$ & $4,3 \pm$ \\
& 0,4 & 0,7 & 0,5 & 0,4 & 0,9 \\
PLO & 0 & 0 & 0 & 0 & 0 \\
\hline
\end{tabular}

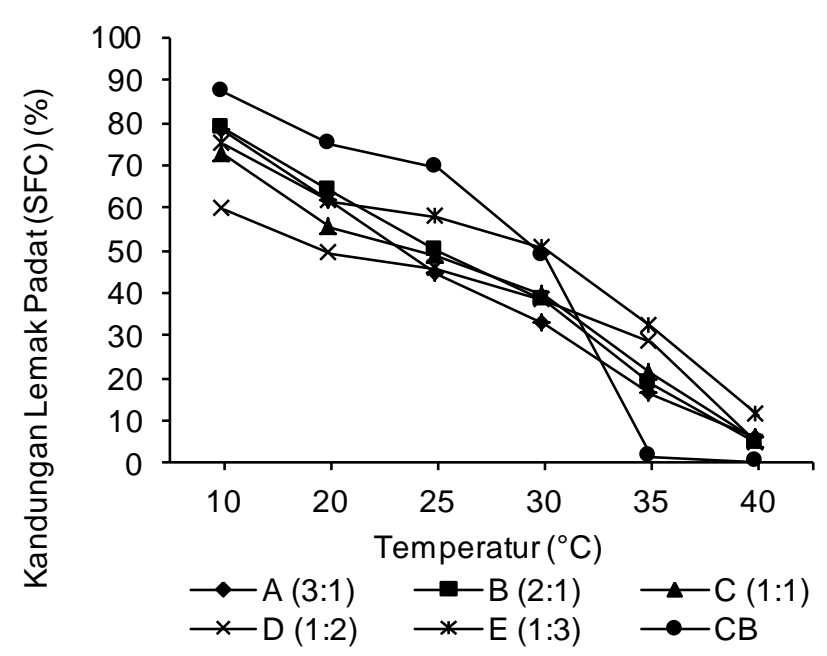

Gambar 2. Profil SFC POP fat yang dihasilkan

Tabel 4. Titik leleh produk POP fat

\begin{tabular}{|c|c|}
\hline Rasio RBDPO/HSOL & Titik leleh $\left({ }^{\circ} \mathrm{C}\right) \mathrm{n}=2$ \\
\hline $3: 1$ & $37,2 \pm 0,5$ \\
\hline $2: 1$ & $35,0 \pm 0,6$ \\
\hline 1:1 & $35,2 \pm 0,6$ \\
\hline $1: 2$ & $35,0 \pm 0,8$ \\
\hline $1: 3$ & $39,0 \pm 0,4$ \\
\hline $\mathrm{CB}^{\prime}$ & $32-35$ \\
\hline $\mathrm{CBE}(\mathrm{POP} \text { fat })^{<}$ & $30,5-33,5$ \\
\hline
\end{tabular}

Hasibuan dan Siahaan, 2013
Rendemen POP fat yang dihasilkan pada penelitian ini berkisar antara 18,3-38,3\% dari berat awal RBDPO. Beberapa peneliti lain menghasilkan produk CBE dengan rendemen yang berbeda-beda antara lain 45,6\% (Abigor et al., 2003), 55\% (Pinyaphong dan Phutrakul, 2009) dan 20,5\% (Soekapotijo et al., 2009). Rendahnya rendemen yang diperoleh pada penelitian ini disebabkan terjadinya reaksi penyabunan antara trigliserida dengan natrium metoksida yang berlebih. Meskipun demikian, rendemen POP fat yang dihasilkan dari penelitian ini lebih tinggi dibandingkan yang diperoleh secara komersial dengan 5 kali fraksinasi yaitu sebesar $14-15 \%$ dari bahan baku (Elisabeth, 2009). Dengan demikian, interesterifikasi antara RBDPO dengan HSOL dan fraksinasinya dapat digunakan sebagai teknik alternatif dalam memproduksi POP fat.

\section{Karakteristik POP fat}

POP fat yang memiliki kemiripan titik leleh dengan $\mathrm{CB}$ yaitu sebesar $35^{\circ} \mathrm{C}$ diperoleh pada rasio berat RBDPO dan HSOL 2:1 dan 1:2 melalui interesterifikasi kimiawi dan fraksinasinya (Tabel 4) namun komponen POP-nya berbeda masing-masing 68,2 dan 62,7\%. Menurut Gibon et al., 2009 bahwa POP fat dikategorikan sebagai CBE dengan komponen POP sebesar $65-70 \%$. POP fat yang diperoleh dari rasio 2:1 memiliki kemiripan komposisi asam lemak dengan produk komersial yang dihasilkan dari fraksinasi RBDPO secara multi-tahap dengan 5 kali fraksinasi (Tabel 5).

Bilangan iodin dari POP fat atau CBE yang dihasilkan pada penelitian ini menyerupai CB. Naik dan Kumar, 2014 melaporkan bahwa bilangan iodin CB sebesar 32-35 Wijs. Bilangan iodin, titik leleh dan komposisi asam lemaknya juga masuk ke dalam range POP fat yang telah dilaporkan oleh Hasibuan dan Siahaan, 2013. Ditinjau dari komposisi trigliserida dari POP fat penelitian ini ada beberapa komponen yang mirip dengan produk komersial seperti POP, PLP, POS dan POO, sementara PPP, MOP dan PPS lebih tinggi. Hal ini yang menyebabkan titik leleh dan kandungan lemak padat pada suhu 35 dan $40^{\circ} \mathrm{C}$ produk dari penelitian ini lebih tinggi. Perbedaan komponen trigliserida pada produk diduga karena proses pembuatannya juga berbeda. Menurut Elisabeth, 2009 bahwa POP fat komersial diperoleh dari RBDPO yang difraksinasi secara multi tahap tanpa pelarut sementara penelitian ini, RBDPO diinteresterifikasi dengan HSOL kemudian difraksinasi menggunakan pelarut pada suhu rendah $\left(4^{\circ} \mathrm{C}\right)$.

Kelemahan CBE yang dihasilkan dari penelitian ini dibandingkan dengan $\mathrm{CB}$ adalah kandungan lemak padat pada suhu $30^{\circ} \mathrm{C}$ relatif rendah sementara 35 dan $40^{\circ} \mathrm{C}$ relatif tinggi. Hal ini berdampak pada aplikasinya dalam pembuatan cokelat karena 
sulit mencair di dalam mulut. Namun demikian, produk ini sangat sesuai apabila diaplikasikan pada cokelat di iklim tropis agar cokelat tidak mudah mencair pada suhu ruang.

Tabel 5. Karakteristik POP fat

\begin{tabular}{|c|c|c|c|c|}
\hline \multicolumn{2}{|c|}{ Parameter } & $\begin{array}{l}\text { POP Fat } \\
\text { Penelitian }\end{array}$ & $\begin{array}{l}\text { POP Fat } \\
\text { Komersial }\end{array}$ & $\begin{array}{c}\text { POP Fat } \\
\text { (Hasibuan } \\
\text { dan Siahaan, } \\
\text { 2013) }\end{array}$ \\
\hline \multicolumn{2}{|c|}{ Bil, lod (Wijs) } & 33,9 & 35,0 & $33,84-36,24$ \\
\hline \multicolumn{2}{|c|}{$\begin{array}{l}\text { Titik leleh } \\
\left({ }^{\circ} \mathrm{C}\right)\end{array}$} & 35,0 & 32,2 & $30,5-33,5$ \\
\hline \multirow{12}{*}{ 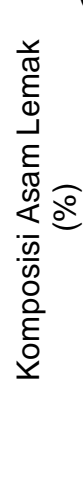 } & C12:0 & 0,1 & 0,1 & $0,03-0,21$ \\
\hline & C14:0 & 1,0 & 0,7 & $0,38-1,04$ \\
\hline & C16:0 & 57,7 & 56,2 & $53,74-58,30$ \\
\hline & C16:1 & 0,1 & 0,1 & ND- 0,14 \\
\hline & C18:0 & 5,1 & 5,4 & $4,33-6,49$ \\
\hline & C18:1 & 32,2 & 34,0 & $32,02-35,92$ \\
\hline & C18:2 & 3,4 & 3,1 & $1,75-4,45$ \\
\hline & C18:3 & 0 & 0 & ND-0,32 \\
\hline & C20:0 & 0,3 & 0,4 & ND-0,21 \\
\hline & $\mathrm{C} 22: 0$ & 0 & 0,1 & ND-0,09 \\
\hline & 10 & 78,3 & 91,1 & $85,47-95,71$ \\
\hline & 20 & 63,8 & 82,9 & $80,73-84,43$ \\
\hline \multirow{10}{*}{$\frac{1}{\omega} \stackrel{0}{\circ}$} & 25 & 49,7 & 71,1 & $64,98-76,01$ \\
\hline & 30 & 38,2 & 48,1 & $44,61-51,51$ \\
\hline & 35 & 18,4 & 6,2 & $3,99-7,84$ \\
\hline & 40 & 4,6 & 0 & ND-0,09 \\
\hline & MMP & 0 & 0,1 & \\
\hline & MPP & 0 & 0,7 & \\
\hline & PPP & 4,5 & 2,6 & \\
\hline & MOP & 4,5 & 1,7 & \\
\hline & MLP & 0 & 0,1 & \\
\hline & PPS & 2,4 & 0,2 & \\
\hline \multirow{14}{*}{ 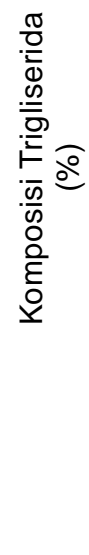 } & POP & 68,2 & 68,4 & \\
\hline & PLP & 4,8 & 4,3 & \\
\hline & PSS & 0 & 0,1 & \\
\hline & POS & 10,8 & 11,9 & \\
\hline & POO & 4,6 & 4,7 & \\
\hline & PLO & 0 & 1,3 & \\
\hline & PLL & 0 & 0,2 & \\
\hline & SSS & 0 & 0 & \\
\hline & SOS & 0 & 1,1 & \\
\hline & SOO & 0 & 0,4 & \\
\hline & 000 & 0 & 0,6 & \\
\hline & SLO & 0 & 0,2 & \\
\hline & OLO & 0 & 0,1 & \\
\hline & SOA & 0 & 0,1 & \\
\hline
\end{tabular}

\section{KESIMPULAN}

Interesterifikasi RBDPO dengan HSOL secara kimiawi dilanjutkan dengan fraksinasi dua tahap dapat menghasilkan produk POP fat dengan kandungan POP dan POS yang tinggi masingmasing sebesar 68,2 dan 10,8\%. Produk ini dikategorikan sebagai CBE karena sifat fisikanya menyerupai cocoa butter (CB) dengan titik leleh sebesar $35^{\circ} \mathrm{C}$ dan kandungan lemak padat pada suhu $30^{\circ} \mathrm{C}$ sebesar $38,2 \%$. Produk yang memiliki kemiripan dengan $\mathrm{CB}$ diperoleh dengan substrat RBDPO:HSOL pada rasio 2:1.

\section{DAFTAR PUSTAKA}

Abigor RD, Marmer WN, Foglia TA, Jones KC, Diciccio RJ, Ashby E, Uadia PO. 2003. Production of cocoa butter-like fats by the lipase-catalyzed interesterification of palm oil and hydrogenated soybean oil. J AM Oil Chem Soc 80: 1193-1196. DOI: 10.1007/s11746-0030841-7.

Amir RA, Shabbir MA, Khan MR, Hussain S. 2012. Interesterification of fats and oils-a review. Pakistan J Food Sci 22: 143-153.

[AOCS] American Oil Chemists' Society. 1997. Official and Recommended Methods of the American Oil Chemists' Society. $5^{\text {th }}$ Ed. Champaign IL.

Ciftci ON, Fadiloglu S, Kowalski B, Gogus F. 2008. Synthesis of cocoa butter triacylglicerols using a model acidolysis system. Grasas Aceites 59: 316-320. DOI: 10.3989/gya.2008. v59.i4.524.

Elisabeth JE. 2009. Pengalaman industri kelapa sawit dalam diversifikasi produk olahan hilir. Prosiding Pertemuan Teknis Kelapa Sawit. 95103, Pusat Penelitian Kelapa Sawit, Jakarta.

Fauzi SHM, Rashid NA, Omar Z. 2013. Effects of chemical interesterification on the physicchemical properties of palm stearin, palm kernel oil and soybean oil blends. Food Chem 137: 817. DOI: 10.1016/j.foodchem.2012.09.086.

Gibon V, Dijckmans P, Calliauw G, Goderis B, Greyt WD. 2009. Study of crystallization properties of soft palm mid fractions for specialty fats production. Euro Fed Lipid Congress: Lipids Fats and Oils, From Knowledge to Application Edition:7 location:Graz, Austria date:18-21 October 2009. Diakses melalui https://lirias. kuleuven.be/handle/123456789/293492. [12 Januari 2014].

Hasibuan AH. 2012. Kajian mutu dan karakteristik minyak sawit Indonesia serta produk fraksinasinya. J Standardisasi 14: 13-21.

Hasibuan AH, Siahaan D. 2013. Karakteristik CPO, Minyak Inti Sawit dan Fraksinya. Buku Saku Seri 31. 45-50. Penerbit: Pusat Penelitian Kelapa Sawit.

Hossain MB. 2013. Applications of palm oil and palm kernel oils in different food products of Bangladesh. J Sci Technol 8: 33-38. 
Idris NA, Dian NLHM. 2005. Interesterification palm products as alternatives to hydrogenation. Asia Pacific J Clin Nutr 14: 396-401.

Jahurul MHA, Zaidul ISM, Nik Norulaini NA, Sahena F, Kamaruzzaman BY, Ghafoor K, Omar AKM. 2014. Cocoa butter replacers from blends of mango seed fat extracted by supercritical carbon dioxide and palm stearin. Food Res Int 65: 401-406. DOI: 10.1016/j.foodres.2014.06. 039.

Kadivar S, De Clerca N, Van De Walle D, Dewettinck K. 2013. Optimisation of enzymatic synthesis of cocoa butter equivalent from high oleic sunflower oil. J Sci Food Agric 94: 13251331. DOI: $10.1002 /$ jsfa.6414.

Liu KJ, Chang HM, Liu KM. 2007. Interesterification of lard and tristearin in supercritical carbon dioxide by lipase enzymatic synthesis of cocoa butter analog. Food Chem 100: 1303-1311. DOI: 10.1016/j.foodchem.2005.12.010.

Mohamed IO. 2012. Lipase-catalyzed synthesis of cocoa butter equivalent from palm olein and saturated fatty acid distillate from palm oil physical refinery. Appl Biochem Biotechnol 168: 1405-1415. DOI: 10.1007/s12010-012-9866-6.

Mohamed IO. 2013. Lipase-catalyzed acidolysis of palm mid fraction oil with palmitic and stearic fatty acid mixture for production of cocoa butter equivalent. Appl Biochem Biotechnol 171: 65566. DOI: 10.1007/s12010-013-0381-1.

Naik B, Kumar V. 2014. Cocoa butter and its alternatives: a review. J Bioresource Eng Technol 2: 111.

Nazaruddin R, Zakiyani SN, Mamot S. 2011. The effect of enzymatic alcoholysis on the physicochemical properties of commercial cocoa butter substitutes. Pakistan J Nutr 10: 718-723.

Pinyaphong P, Phutrakul S. 2009. Synthesis of cocoa butter equivalent from palm oil by Carica papaya lipase-catalyzed interesterification. Chi- ang Mai J Sci 36: 359-368. DOI: 10.1007/s1174 6-014-2412-7.

Shekarchizadeh H, Kadivar M, Ghaziaskar HS, Rezayat M. 2009. Optimization of enzymatic synthesis of cocoa butter analog from camel hump fat in supercritical carbon dioxide by response surface method (RSM). J Supercrit Fluid 49: 209-215. DOI: 10.1016/j.supflu.2009. 03.005.

Shekarchizadeh H, Tikani T, Kadivar M. 2014. Optimization of cocoa butter analog synthesis variables using neural networks andd genetic algorithm. J Food Sci Technol 51: 2099-2105. DOI: 10.1007/s13197-012-0695-y.

Soekapitojo S, Hariyadi P, Muchtadi TR, Andarwulan N. 2009. Enzymatic interes-terification of palm oil mid fraction blends for the production cocoa butter equivalents. Asian J Food AgroInd 2: 807-816.

Soekapitojo S. 2011. Asidolisis enzimatik fraksi tengah minyak sawit dengan asam stearat untuk sintesis cocoa butter equivalents. J Teknol Kejuruan 34: 203-216.

Tchobo FP, Piombo G, Pina M, Soumanu MM, Villeneuve P, Sohounhloue DK. 2009. Enzymatic synthesis of cocoa butter equivalent through transesterification of pentadesma butyraceae butter. J Food Lipids 16: 605-617. DOI: 10.1111/j.1745-4522.2009.01169.x.

Zaidul ISM, Norulaini NAN, Omar AKM, Smith RL. 2007. Blending of supercritical carbon dioxide $\left(\mathrm{SC}-\mathrm{CO}_{2}\right)$ extracted palm kernel oil fractions and palm oil to obtain cocoa butter replacers. J Food Eng 78: 1397-1409. DOI: 10.1016/j.jfood eng.2006.01.012.

Zaliha O, Norizzah AR. 2012. Physicochemical properties and compatibility study on palm oil products with cocoa butter. J Oil Palm Res 24: 1349-1352. 